\title{
INFLUENCE OF LUXURY COMPANIES' CORPORATE SOCIAL RESPONSIBILITY ACTIVITIES ON CONSUMER PURCHASE INTENTION: DEVELOPMENT OF A THEORETICAL FRAMEWORK
}

Olšanová, K., Cook, G., Zlatić, M.

The topics of sustainability and strategic corporate social responsibility are currently being discussed by different stakeholders on academic, industry and various activist levels; however, the level to which they are incorporated into organizations' strategy varies significantly by industry. The needs of the customers as well as the requirements from state governance may challenge the currently relatively "CSR silent" luxury industry to become more active in its contribution to social responsibility. This paper investigates the topic of corporate social responsibility within the context of the luxury industry, the extent to which customers are aware of CSR and the significance of the role it plays in their customer journey. The authors provide a literature review focused on exploring CSR variables that impact customer purchase intention in general and specifically in the luxury segment, from which they identify key CSR measures and conduct qualitative research to develop a theoretical framework. It suggests that purchase intention in the luxury segment is dependent on the luxury values, individual sustainable dimension and awareness of the brand's CSR, the last two relationships being potentially moderated by certain conditions such as demographics and general positive attitudes towards CSR and sustainability. The model's output is in the formulation of several propositions for further research. Overall, the qualitative interviews indicate that while knowledge of the specific CSR activities of particular luxury brands was low, luxury buyers in this research tend to express quite positive attitudes towards CSR in general, were rational, and very open to considering CSR as an added value to their luxury shopping.

Keywords: CSR, luxury industry, purchase intention, purchase intention for luxury brands JEL Classification: M31

\section{Introduction}

On 25 September 2015, at the United Nations Sustainable Development Summit in New York, the "Sustainable Development Goals" (SDGs) were agreed to by the global community. Governments have the primary responsibility for following-up on and 
reviewing them as well as monitoring progress made in their implementation prior to the target date of 2030. The 17 SDGs with their 169 targets adopted to be relevant for each country are continuously being incorporated into national planning processes, policies and strategies and reviewed by the High-level Political Forum on Sustainable Development, which is the central UN platform. To make a clear connection with the objectives of this article, Goal 12 (Ensure sustainable consumption and production patterns) should be mentioned, as it provides nations clear targets in sustainable management and efficient use of natural resources, in reducing waste generation and most importantly, encourages especially large, transnational companies to adopt sustainable practices and to integrate sustainability information into their reporting cycle. Similarly, SDG-8 (Decent work and economic growth) aims to promote sustained, inclusive and sustainable economic growth, full and productive employment and decent work for all (United Nations, 2015).

However, as reported by The European Business Network for Corporate Social Responsibility (CSR Europe), based on interviewing representatives of industry leaders by GlobeScan and Frost \& Sullivan research, "the full integration of the SDGs into business planning has a long way to go". Awareness of the SDGs was found to be very low, and limited to top management and those in CSR or sustainability functions (CSR Europe, 2017). In order to fulfill the SDGs on a national level, companies will need to "deeply engage their middle management and employees to raise awareness and interest in the SDGs and unlock innovation" (CSR Europe, 2017, p. 26).

Work toward SDGs, and especially Goal 12, is supposed to be led by developed countries; prominent global industries must also be active. The automotive and food categories serve as examples of large industries that have significantly incorporated activities focused on CSR and sustainability into their planning and strategy processes. Companies like Unilever or Nestlé are industry examples that have incorporated the SDGs into their sustainable business strategies (Haski-Leventhal, 2018, p. 137). Other examples come from tobacco or the fast food industry, which for various reasons, passed through the CSR threshold ("the point at which CSR becomes a necessary component of strategic success") long ago (Chandler, 2017, p. 228). The luxury industry cannot be an exception. In FY2015, sales of the top 100 luxury goods companies totaled USD 212 billion. This is an average of USD 2.1 billion per company (Deloitte, 2017). From the perspective of the size of the industry, luxury might evolve into a strong socially responsible segment with access to the resources needed. There are already a few examples where luxury companies incorporate SDGs into their strategy. For example, Kering SA - the 6th largest luxury brands producer according to sales in 2015 (Deloitte, 2017) - aligned its sustainability efforts across its 16 luxury brands with the SDGs in 2017 by implementing low-carbon economy. Guided by the SDGs, they quantified specific targets in their strategy, under the three themes of: Care, Collaborate and Create (Sustainable Brands, 2017).

However, there is another important stakeholder needed in the creation of a responsible luxury segment, i.e. the luxury customer. According to the Deloitte Luxury Multicountry 
Survey for Global Powers of Luxury Goods conducted in 2017, the luxury segment is strongly influenced by VIPs, designers, actors, musicians, YouTubers, rich people, fashion bloggers, etc. (Deloitte, 2017, p. 9). Linking these top influencers with an organization's CSR might be the right tool to help create a socially responsible segment with overlap to other industries. Therefore, the luxury customer and his/her attitudes towards CSR in general and towards the CSR activities of luxury brands is the focus of this paper. To inspire the luxury industry to communicate its CSR activities more, we need to connect the purchase intention of luxury customers to the sustainability and responsibility efforts of a company as an extension to more obvious purchase intention drivers.

Therefore, the key objective of this study is to explore the relationships of different CSR measures and customers' purchase intention within the luxury segment. To achieve this, we have examined previously conducted research to investigate existing measures influencing purchase intention within the luxury industry, and then follow up ourselves by conducting a series of in-depth interviews with luxury customers to better understand the meanings of the relevant measures. Based on interpretation of the results, we introduce a conceptual framework that illustrates the relationships between identified CSR measures and luxury purchase intention as a foundation for development of a set of research propositions.

The article is structured in the following manner. After the introduction, we provide a review of the existing literature. In the next section, an overview of the research method is given. The paper's major findings are covered in part four. This is followed by a section that details the development of the conceptual framework as well as the propositions, to be used in a future quantitative study. Finally, concluding remarks are presented.

\section{Literature Review}

\subsection{Sustainability and sustainable development}

The term sustainability was framed and popularized in 1987 by the so-called Brundtland Report. In this report, sustainability was defined, as "Sustainable development is development that meets the needs of the present without compromising the ability of future generations to meet their own needs" (United Nations, 1987). As result of this broad definition, the term sustainability is currently perceived to mean, "issues related to the natural environment" (Chandler, 2017, p. 285).

Sustainability, as defined above, is the basis for definition of sustainable development, being defined as "a process of change in which the exploitation of resources, the direction of investments, the orientation of technological development; and institutional change are all in harmony and enhance both current and future potential to meet human needs and aspirations" (United Nations, 1987). 
According to Chandler, Co-Director of the Managing for Sustainability Program at the University of Colorado Denver's Business School, there are four main reasons why businesses should care about sustainability: climate change, resilience, natural capital, and stakeholders. Table 1 provides more explanation and the connectivity between these four factors. Accommodation of effective sustainability programs as a key component of the long-term strategy is the most important tool to address the issue by different businesses.

Table 1 | Key reasons for business involvement in sustainability

\begin{tabular}{|c|c|c|c|c|}
\hline & Climate Change & Resilience & Natural Capital & Stakeholders \\
\hline 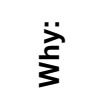 & $\begin{array}{l}\text { Consequences of } \\
\text { climate change }\end{array}$ & Managing risks & $\begin{array}{l}\text { Act voluntarily } \\
\text { before you are } \\
\text { forced to change }\end{array}$ & $\begin{array}{l}\text { Stakeholders' } \\
\text { perceptual change }\end{array}$ \\
\hline 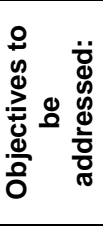 & $\begin{array}{l}\text { Businesses to } \\
\text { change the way they } \\
\text { interact with the } \\
\text { natural environment }\end{array}$ & $\begin{array}{l}\text { Help vulnerable } \\
\text { people, } \\
\text { organizations and } \\
\text { systems persist, } \\
\text { even thrive, amid } \\
\text { unforeseeable } \\
\text { disruptions }\end{array}$ & $\begin{array}{l}\text { Identify the ways to } \\
\text { account for the } \\
\text { natural capital that } \\
\text { they consume } \\
\text { during production }\end{array}$ & $\begin{array}{l}\text { To accommodate } \\
\text { stakeholders' needs } \\
\text { in terms of their } \\
\text { increasing demand } \\
\text { for change }\end{array}$ \\
\hline$\frac{\substack{c \\
\mathbb{d}}}{\frac{0}{2}}$ & $\begin{array}{l}\text { Getting the balance } \\
\text { between current and } \\
\text { future obligations } \\
\text { correct }\end{array}$ & $\begin{array}{l}\text { Search for ways to } \\
\text { manage in an } \\
\text { imbalanced world. } \\
\text { Dependence of } \\
\text { business success } \\
\text { on accounting for a } \\
\text { changing ecological } \\
\text { context and } \\
\text { adapting operations } \\
\text { accordingly }\end{array}$ & $\begin{array}{l}\text { Calculate the value } \\
\text { of natural capital } \\
\text { (the resources } \\
\text { exploited for free) } \\
\text { and incorporate it } \\
\text { into the planning }\end{array}$ & $\begin{array}{l}\text { Accommodate } \\
\text { effective sustainability } \\
\text { programs as a key } \\
\text { component of long- } \\
\text { term strategy }\end{array}$ \\
\hline
\end{tabular}

Source: Adapted based on Chandler, 2017, pp. 284-301.

\subsection{Evolution of CSR}

In line with the objectives of this article related to the CSR impact on purchase intention within a specific industry, our understanding of CSR correlates with the strategic perception of CSR: "Strategic CSR is the incorporation of a holistic CSR perspective within a firm's strategic planning and core operations so that the firm is managed in the interests of a broad set of stakeholders to optimize value over the medium to long term"; CSR being defined as "A responsibility among firms to meet the needs of their stakeholders and a responsibility among stakeholders to hold firms to account for their actions" (Chandler, 2017, p. 248); or as "a firm's commitment to maximize long-term economic, societal and environmental well-being through business practices, policies and resources (Du et al., 2011, p. 1528). Du et al.'s (2011) definition is also appropriate for this article, as it is mostly connected with business and consumers at the same time. It supports the idea that CSR is an umbrella for three dimensions - economic development, social 
equity and an environmental dimension, as also referred to in Chandler's definition (Du et al., 2011).

The evolution of CSR towards Strategic CSR at the beginning of this decade has roots in Porter and Kramer's "creating shared value" (CSV) concept defined as "policies and operating practices that enhance the competitiveness of a company while simultaneously advancing the economic and social conditions in the communities in which it operates. Shared value creation focuses on identifying and expanding the connections between societal and economic programs" (Moon et al., 2011). After the publication of Porter and Kramer's article in 2011, some companies (Nestlé, Unilever, Kraft Foods as examples) replaced CSR with CSV (Haski-Leventhal, 2018, p. 43). CSR, on the other hand, has its roots in the publications of one of the first academics working on CSR hierarchy, A. Carroll, whose pyramid of responsibilities covers philanthropic, ethical, legal and economic (Figure 1). In his vision, a socially responsible firm encompasses all four responsibilities within its culture, values and day-to-day business (Chandler, 2017).

Figure 1 | Carroll's pyramid of business responsibility

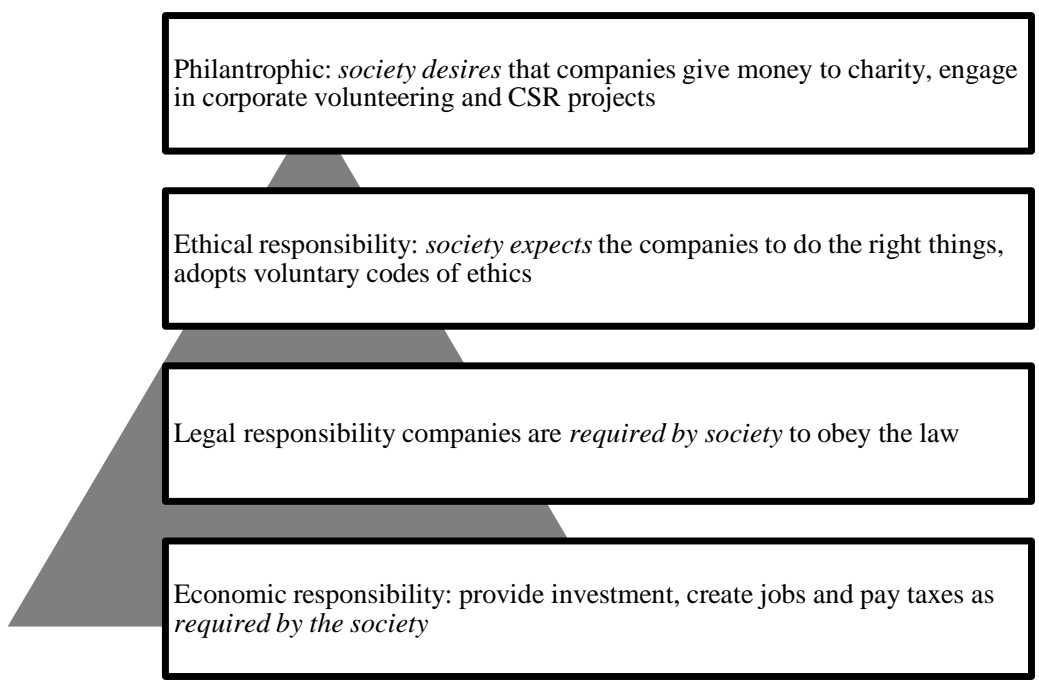

Source: Adaptation based on Carroll (1991) and Haski-Leventhal (2018, p. 32).

From the economic standpoint, CSR adds value because it allows companies to address the needs and concerns of their various stakeholder groups. By doing so, the firm is more likely to create greater value and, as a result, retain the loyalty of those stakeholders. 
Simply put, CSR is a way of matching corporate operations with stakeholder values and expectations that are constantly evolving (Chandler, 2017). Currently the economic argument for CSR is perceived as the last stage of CSR development where it brings true value to a company's business as opposed to earlier understandings where philanthropy or discretionary arguments created costs for the company, rather than being a valued added for the business.

The consolidative model of CSR integration into companies, its stakeholders and strategies was characterized by a three-phase CSR cultural model. Maon et al.'s (2010) three developmental phases are categorized into cultural resistance, cultural grasp and embedment, and are briefly overviewed in Table 2 below.

Table 2 | Three phases of CSR cultural development by Maon et al. (2010)

\begin{tabular}{|l|l|l|}
\hline Phase & Key Features & $\begin{array}{l}\text { Stakeholder type according to } \\
\text { their moral orientation }\end{array}$ \\
\hline $\begin{array}{l}\text { CSR Cultural } \\
\text { Reluctance }\end{array}$ & $\begin{array}{l}\text { CSR perceived as a constraint, no CSR related } \\
\text { goals, ignoring social responsiveness. }\end{array}$ & $\begin{array}{l}\text { Limited morality: corporate } \\
\text { egoists, short-term self-interest at } \\
\text { the corporate level. Shareholders } \\
\text { as the only stakeholders. }\end{array}$ \\
\hline $\begin{array}{l}\text { CSR Cultural } \\
\text { Grasp }\end{array}$ & $\begin{array}{l}\text { CSR as a value protector of organizational } \\
\text { goals. Focus on reputation, tangible results and } \\
\text { adaptation of existing processes in the short- } \\
\text { term. }\end{array}$ & $\begin{array}{l}\text { Enlightened self-interest moral } \\
\text { orientation. Concern for others is } \\
\text { fairly self-regarding. } \\
\text { Instrumentally useful } \\
\text { stakeholders. }\end{array}$ \\
\hline $\begin{array}{l}\text { CSR Cultural } \\
\text { Embedment }\end{array}$ & $\begin{array}{l}\text { Integrative approach to CSR responsiveness. } \\
\text { CSR commitments with large impact - from } \\
\text { business opportunities to social change. CSR } \\
\text { perceived as value creator for the organization, } \\
\text { focus on innovations and long-term prospects. }\end{array}$ & $\begin{array}{l}\text { Concern for others, normative } \\
\text { stakeholders (competitors, media, } \\
\text { activists' groups), derivative } \\
\text { stakeholders. Pragmatism and } \\
\text { pure intrinsic morality. }\end{array}$ \\
\hline
\end{tabular}

Source: Adapted from Maon et al. (2010), p. 30.

Within the cultural embedment phase, the organization develops a culturally integrated approach to CSR, through which it tries to maximize opportunities and create value through CSR commitments, creative processes and joint innovations with external stakeholders (Maon et al., 2010).

The moment when CSR becomes an essential part of a company's culture, organization and processes, it will integrate and respect three critical components: the organization's self-interests, its rights and also its responsibilities. The overlapping area of these three components creates a place or "strategic CSR zone for meaningful economic change". To the extent that the responsibilities expected of it do not infringe upon its rights and align with its self-interest, the chance of introducing meaningful change and building a more sustainable economic model increases (Chandler, 2017).

\subsection{The luxury industry and CSR}


The most quoted core values of luxury are scarcity or limited accessibility, heritage, aesthetics and sophistication, high desirability, excellent quality, high price, extraordinariness and high degree of non-functional associations (Heine, 2012; Dubois \& Paternault, 1995). The basic drivers of customer value perception that influence consumer behavior in the luxury industry - in terms of helping to differentiate the brands and forming desire for luxury brands - were empirically validated by Hennings et al. (2015); they are: financial, functional, social and individual consumer perceptions. Amongst them, the perceived social values of the luxury brands had the strongest effects in terms of its positive relation to the total construct of individual luxury value perception (Hennings et al., 2015).

Luxury brands sell products that are rare, and are thus resource-dependent, which increases their need for sustainability (Kale \& Öztürk, 2016). Kapferer and Michaut-Denizeaut (2014) described sustainability in the luxury industry as "sustainability silence" because only a few luxury companies take a proactive stance in sustainable development. This sector is clearly aware of the issues but remains discreet, which some critics interpret as uninvolved (Kapferer \& Michaut-Denizeaut, 2014).

Despite the "silence", a systematic review of the sustainable behavior of luxury companies indicated that these companies are showing some progress (for example, IWC has committed to becoming carbon-neutral, Kering SA has a commitment to SDGs as mentioned earlier, etc.) but mostly they still approach CSR with a combination of disorganized philanthropy, glamorous sponsorship projects and the management of reputational risks (Bendell \& Kleanthous, 2007). The luxury segment's understanding of CSR is far away from the engagement level of more developed industries (consider the food or automotive industries as examples), and it is obvious that unless they become more engaged in this agenda, they will miss out on opportunities to create additional value through CSR, enabling them to further connect with their customers. There are cases when a company undertakes activities to address the public concerns mentioned above by managing reputational risks without deeper engagement in strategic sustainability and CSR. Gucci, as an example, has recently announced they would stop selling or producing items made with animal fur. They obliged themselves to auction off fur items from their inventory and donate all proceeds to animal rights organizations, i.e. the Humane Society (in the US) and LAV (in Italy). The company is additionally joining the International Fur Free Alliance (Trendwatching, 2018). The Italian house Gucci has visibly joined Calvin Klein, Giorgio Armani, and Ralph Lauren in banning fur from their collections. Recently, Yoox Net-a-Porter Group (Net-a-Porter, Mr Porter, The Outnet and Yoox) also declared that it would no longer sell fur products on its e-commerce sites (Positive Luxury, 2017). There are discussions, however, that the environmental impact of real fur compared to artificial fur is lower due to the fact that fake plastic fur is extremely harmful to the environment, isn't biodegradable and negatively impacts wildlife, due to the petroleum and plastics used to produce it (Positive Luxury, 2017). 
Content analyses of the CSR messages amongst luxury industry companies were done by Wong \& Dhanesh (2017). They analyzed each dimension of the CSR message content amongst the most valued luxury brands with a qualitative framework analysis creating detailed framework matrices of each dimension. The outcome of this study was that luxury brands predominantly framed their CSR efforts "as going beyond what is required driven by purely good-hearted, altruistic motives” (Wong \& Dhanesh, 2017, p. 434). Moreover, the framework emphasized that the supported programs were congruent with their core business values and the impact of CSR programs was conveyed in abstract terms evoking emotions over logic (Wong \& Dhanesh, 2017). Robertson's (2018) review of this research summarized that "CSR within the luxury world is positioned as altruistic and exceptional, rising both the brand and the customer above the banality of the everyday through working to improve the society" (Robertson, 2018). In other words, we could characterize the CSR activities of most luxury brands as being in the phase of "CSR Reluctance", slowly moving towards “CSR Cultural Grasp” (Maon et al., 2010), as described in Table 2.

The current issues the luxury industry is facing, in terms of the existing known public concerns, were listed by Bendell and Kleanthous (2007); they are: the role of precious stones in financing conflicts; the impacts of mining operations; worker rights in companies and their supply chains; responsible marketing; and the trade in wildlife-derived products (Bendell \& Kleanthous, 2007). Kapferer was more specific in naming the potential issues in luxury as those referring to hidden parts of the supply chain, such as raw material sourcing (for example, checking the source of all animal skins, gold, gemstones), animal treatment (for example, the anti-foie gras lobby, exploitation of crocodile farms, killing baby seals for fur, etc.), human work conditions (for example, gold), manufacturing methods polluting the local environment (for example, mercury for tanning skins), or destruction of the environment (for example, endangered tree species used in the luxury furniture business, exploitation of rare water resources by luxury golf clubs and hotels situated in poor countries) (Kapferer \& Michaut-Denizeaut, 2014). It was indicated that "luxury buyers' interest in sustainability when purchasing luxury goods is still relatively minimal” (Kapferer \& Michaut-Denizeaut, 2014).

\subsection{CSR's impact on purchase intention}

It is obvious that once it is proven that purchase intention is impacted by CSR activities, an industry will accelerate its efforts in this regard. The literature suggests that there is a link between CSR and purchase intention in general, though not specifically related to the luxury segment. Mohr and Web (2005) indicated that CSR (measured by environmental and philanthropic dimensions) had a significant, positive effect on the evaluation of a company and purchase intent. Their approach was artificial though, not specifically related to any existing brand. Additionally, they noted that when consumers had no information about a company's CSR, they assumed that it was behaving responsibly. The relationship between CSR activities and the personal values of consumers is through purchasing and being helpful to others (Mohr \& Webb, 2005; Bhattacharya \& Sen, 2004). Importantly, perceived CSR was identified as a moderating effect on the relationship between negative 
publicity and affective identification of negative publicity by customers (Lin et al., 2011; Mohr \& Webb, 2005). Therefore, CSR may influence purchase intention through absorbing negative publicity related to various issues (Lin et al., 2011). The positive relationship between consumer awareness of a company's CSR activities and purchase intention was supported by Sharma et al. (2018). They confirmed positive impact of CSR variables, namely loyalty, morality, awareness, environment and behavior on purchase intention. CSR-driven morality was the most important factor impacting purchase intention, followed by CSR awareness and environmentally-driven CSR.

The research of Ho et al. (2016) aimed at understanding different segments of luxury customers and identifying those where CSR plays an important role in purchase intention. Their findings indicate that CSR plays a stronger role in the purchasing decisions of consumers with internal value expressive perceptions than with consumers having external value expressive perceptions.

Understanding of the antecedents of luxury brand purchase intention was deeply analyzed by Hung et al. (2011). Their findings supported the strong influence of social context on purchase intention for luxury brands. The social context was explored through the statements: (i) Before purchasing a luxury branded product, it is important to know what brands will make a good impression on others, (ii) My friends and I tend to buy the same luxury brands, (iii) Before purchasing a luxury branded product, it is important to know what kinds of people buy certains brands, (iv) I tend to pay attention to what other luxury brands others are buying), (v) I like to know what luxury branded products make good impressions on others, and (vi) I actively avoid using luxury branded products that are not in style.

The role of perception formed by functional, experiential and symbolic values was weaker compared to the social one. The experiential (luxury brand $\mathrm{X}$ is precious, rare, unique, attracting, stunning) and functional (is handmade, best quality, sophisticated, superior) aspects of luxury brands were positively correlated with purchase intention. Symbolic values had a weak negative relationship with purchase intemtion (a luxury item is conspicuous, expensive, for the wealthy). In summary, their findings support the influence of the social context on purchase intention for luxury brands while the role or perception was weaker. The experiential and functional aspects of luxury brand purchase were positively correlated with purchase intention, but symbolic value was not. Physical and achievement vanity had a positive impact on purchase intention, while only achievement vanity had a moderating effect on perception. They concluded that the increased exposure of international luxury brands in the media, and the concomitant increase in international awareness and travel would support growth in luxury (Hung et al., 2011). This study was followed up by Cheah et al. (2015) who enriched the model by finding positive relation between brand prominence and purchase intention for luxury brands. They also found that social influence has a significant influence on physical vanity and willingness to buy luxury brands (Cheah et al., 2015). 


\subsection{Key influencing factors from the literature and research objective}

Based on the literature review, the research objective at this stage is to understand the factors that have impact on the recent purchasing decisions of luxury shoppers, and in particular how and whether specific CSR dimensions impact purchase intent. By undertaking this research, we will confirm the measures from the literature review as variables for our theoretical model regarding purchase intention, and then proceed to the quantitative testing phase.

The sustainable dimension reflects Carroll's pyramid, which depicted the economic category as the the foundation for the others, and then built upward through the legal, ethical and philanthropic categories (Carroll, 1991; Carroll, 1999). Carroll's formulation of the aim of a company's CSR is "to make a profit, obey the law, be ethical, and be a good corporate citizen" (Carroll, 1991, p. 43). Our sustainable dimension construct is based on the findings of Alvarado-Herrera et al. (2017), who developed and validated a measurement scale for consumers' perceptions of corporate social responsibility. They proved that consumers' perception of CSR is a multidimensional construct rather than a one-dimensional factor, based on economic, social and environmental dimensions (Alvarado-Herrera et al., 2017). The luxury values' impact on purchase intention follows Hung's factors of symbolic, experiential, functional and social (Hung et al., 2011).

The measures regarding perception of CSR and its awareness were constructed based on application of past research findings by Kapferer \& Bastien (2012) and Davies et al. (2012). Davies et al. (2012) indicated that the ethical impacts of luxury brands have less intensity for consumers during decision-making; this is explained by qualitative data where, in the luxury segment, it was not perceived as making much difference compared to commodities with a higher purchase frequency. The measures of general attitudes towards CSR and sustainability issues are based on Kapferer's consumers' sensitivity to a sustainability measure, which was based on an existing scale developed by the survey organization BVA for the French National Energy Saving Agency (Kapferer \& MichautDenizeaut, 2014).

\section{Research Methods}

Our research framework is based on mixed method or multi-strategy research combining qualitative (current stage) with quantitative methods (next stage) (Bryman, 2006; Sreejesh \& Mohapatra, 2014). Through our initial qualitative research we focus on meanings and gaining a deeper understanding of the relevant issues rather than on quantifiable phenomena; we place emphasis on depth and details as well as sensitivity to context rather than seeking universal generalization, as proposed by (Schutt, 2015). The qualitative part serves as instrument development, employed to develop a questionnaire and scale items, as well as to generate hypotheses for the upcoming quantitative phase (Bryman, 2006). This 
article presents the results of the first stage (qualitative) by introducing the conceptual framework and drawing hypotheses.

\subsection{Data collection procedure}

Within this study, we conducted a series of eight in-depth interviews to explore the attitudinal and behavioral dimensions of luxury customers' relationships towards with the industry and brands. The study's participants were recruited based on their claimed recent purchases of the listed luxury brands. The list included the top brands by sales volume (Deloitte, 2017) combined with brands bought most by European consumers (Dubois \& Laurent, 1993) as well as Interbrand's 2017 ranking (Interbrands, 2017). The final list was drawn as a combination of the above, with emphasis to ensure relevancy for both male and female gender groups, in the European context, through including typical handbags (considered as "the engine that drives luxury brands today", see Han et al., 2010) and watch brands (assumed to play a similar role for men). The final list of brands for prompting in "bought within the last year" can be found in Table 3.

Table 3 | Luxury brands respondents were asked if they had purchased within the last year

\begin{tabular}{|l|l|l|l|}
\hline LV & Burberry & Montblanc & Breguet \\
\hline Hermés & Dior & Vacheron Constantin & Harry Winston \\
\hline Gucci & Chanel & IWC & Rado \\
\hline Cartier & Dior & Ulysse Nardin & Blancpain \\
\hline Tiffany\&Co & Fendi & Omega & Rolex \\
\hline Prada & TAG Heuer & Longines & \\
\hline
\end{tabular}

Source: Authors

The interviews were conducted in Prague, Czech Republic between February and March 2018; respondents were individuals with advanced knowledge of luxury brands. In most cases, interviews were done in person, at various locations, respecting the time constraints of the respondents. One interview was by phone. The interviews were lengthy (40-45 minutes) in order to capture multiple aspects of the discussed dimensions. The specifics of the luxury customers were reflected in the moderating guide (e.g. anonymity of the respondents, no specific questions about family status or income) to ensure the private nature of the interview. Upscale luxury customers are known for strongly protecting their privacy. This constraint prevented the interviews from being audio/video recorded. However, accurate transcriptions - taken by the interviewers during the actual interviews were utilized to record the interviews in electronic documents; this was done with the agreement of respondents. From a demographics point of view, three respondents were between 41-50 years old; the other five were between the ages of 31-40. Three of the participants were male, and five were female. All but one had university level education, the other one completed secondary school. Professionally, they either run their own businesses or occupy high management level positions within international companies. 


\subsection{Data coding and analyses}

The moderating guide for the in-depth-interviews consisted of two parts. Firstly, through a series of semi-structured open questions, respondents were prompted to think about their general attitudes towards sustainability and CSR as well as the connection to luxury brands purchased. In addition, typical buying occasions and the frequency of their luxury shopping excursions were discussed. Secondly, participants were asked to evaluate a set of statements (see Appendix A) in relation to the two most expensive luxury brand purchases they had made within the last year; responses were captured on a Likert scale, and each respondent's specific comments regarding every dimension were recorded. After completion of each interview, two independent coders analyzed the transcripts of the openended questions contained in the first part and the comments from the second part; this was done on a sentence-by-sentence basis, and then a set of behavioral categories was developed to gain a deeper understanding of the respondents' attitudes toward CSR, their luxury shopping habits, and the relations between luxury purchase intention and their expressed relation towards CSR. Consequently, the basic scaling was calculated based on the second part of the interviews, elaborating some indicators for preparation of the conceptual model based on the level of agreement with given statements prior to the quantitative research phase.

\section{Results}

The following core categories were developed and evaluated (Table 4): (i) Luxury need states, (ii) General attitudes towards sustainability and CSR, (iii) CSR pillars' individual importance, and (iv) Perception of individual luxury values.

Table 4 | Categorization of results

\begin{tabular}{|c|c|c|c|}
\hline Core Category & \multicolumn{2}{|l|}{ Category } & Subcategory \\
\hline \multirow[t]{3}{*}{$\begin{array}{l}\text { Luxury need } \\
\text { states }\end{array}$} & \multicolumn{2}{|c|}{ Demonstrate luxury } & $\begin{array}{l}\text { Expensive, various product categories (bags, } \\
\text { watches, scarves, luxury fashion), added value, } \\
\text { upscale quality }\end{array}$ \\
\hline & \multirow[t]{2}{*}{$\begin{array}{l}\text { Buying } \\
\text { occasions }\end{array}$} & $\begin{array}{l}\text { Self- } \\
\text { indulgence }\end{array}$ & $\begin{array}{l}\text { Not necessary but nice to have, added value, to } \\
\text { treat oneself or others, to overcome difficult } \\
\text { situations in life, pleasant activity during the } \\
\text { weekend }\end{array}$ \\
\hline & & Gifting & Christmas, birthdays, to please others, joy of gifting \\
\hline $\begin{array}{l}\text { General attitudes } \\
\text { towards } \\
\text { sustainability and } \\
\text { CSR }\end{array}$ & \multicolumn{2}{|c|}{ CSR perception in general } & $\begin{array}{l}\text { Added value to a company, positive to customers } \\
\text { and employees, factor of repeat purchase, give back } \\
\text { to society, contributing to the community, belief in } \\
\text { technical progress, environmental issues, } \\
\text { connections to policy makers, concerns about } \\
\text { environment degradation, preferences for heathier } \\
\text { products }\end{array}$ \\
\hline \multirow{5}{*}{$\begin{array}{l}\text { CSR pillars' } \\
\text { individual } \\
\text { importance ** }\end{array}$} & \multicolumn{2}{|l|}{ Economic } & $\begin{array}{l}\text { Long-term economic success, improving quality of } \\
\text { services, solid relationship with the customers }\end{array}$ \\
\hline & \multicolumn{2}{|c|}{ Social } & Culture, ethical programs, sponsoring \\
\hline & \multicolumn{2}{|c|}{ Environmental } & Environment protection, natural resources \\
\hline & \multicolumn{2}{|c|}{ Brand's CSR awareness } & $\begin{array}{l}\text { Feel better when purchasing from a socially } \\
\text { responsible company, awareness of a particular } \\
\text { brand's CSR }\end{array}$ \\
\hline & \multicolumn{2}{|c|}{ CSR awareness related to } & Low awareness of any CSR activities in luxury, \\
\hline
\end{tabular}




\begin{tabular}{|l|l|l|}
\hline \multirow{2}{*}{$\begin{array}{l}\text { Perception of } \\
\text { individual luxury } \\
\text { values } * *\end{array}$} & luxury in general & $\begin{array}{l}\text { assumptions that luxury is being responsible, just } \\
\text { legislation driven }\end{array}$ \\
\cline { 2 - 3 } & Symbolic & Striking, expensive and for the wealthy \\
\cline { 2 - 3 } & Functional & Uniqueness, attractiveness, preciousness \\
\cline { 2 - 3 } & Social & Superiority, sophistication, best quality \\
\hline
\end{tabular}

Source: Authors

Note: ** Related to the recently purchased brand.

\subsection{Luxury need states}

Spontaneous associations with luxury included both particular types of products - such as bags, watches, shoes, and apparel as well as associations of superior quality. Goods with "added value" and "upscale quality" were referenced. In particular, luxury goods tend to be associated as those that are "not easily available" or "not necessary to live, but that are nice to have". Frequencies of purchase results support the previous findings of other researchers (Kapferer \& Michaut-Denizeaut, 2014; Davies et al., 2012) who note the infrequent nature of luxury purchases. For the most part, interview participants indicated that they make a luxury purchase "occasionally" - e.g. once or twice per year; however, others make them on a monthly basis. Typical items purchased were the following: watches, bags, shoes and accessories. Interviewees make purchases both to "treat themselves" and also as gifts for Christmas or birthdays. Interestingly, there were also mentions made of luxury shopping as a "distraction" or as a free time activity.

\subsection{General attitudes towards sustainability and CSR}

General attitudes towards CSR and its relevance in the personal lives of the interview participants varied, though there was generally agreement of its importance. The research team observed that respondents with children from Generation $\mathrm{Z}$ were influenced by them in their attitudes towards CSR and shopping decisions: "They [Gen Z] do really care [about] sustainability, they follow their own rules. And they all live like this". The moderating effect of demographic factors should be noted and further explored in the quantitative stage of our study.

With regard to "why organizations do it" and whether that might be for individualistic reasons, the interviewees exhibited conflicting perspectives. Responses varied from skepticism - "they do what is needed to follow the legislation, but otherwise they do not care" - to a lack of knowledge on the topic; others stated their opinions that organizations do it for genuine reasons, i.e. "they truly mean it". They had a tendency to agree that CSR is an added value for companies. The benefits for both employees as well as consumers were mentioned; respondents also stated that they thought it helps improve company image and could be a factor in repeat purchase. When queried about whether CSR is an added value for them when making a luxury purchase, responses were mixed. Approximately half indicated that it was not; however, there were also indications that this was due primarily to lack of knowledge in terms of which companies were doing anything CSR- 
related: "In general no, but if I liked two similar products from different brands, I would buy the one which I knew followed CSR practices."

The respondents' attitudes towards sustainability issues explored in the scaling part seemed to be positive, with a mean of 1.9. Concern about environment degradation as well as a belief in technical progress being able to solve issues related to environmental degradation were agreed upon in the majority of cases. Disagreement was driven by local factors, such as environmental issues being a decision factor when voting during elections or discussion about pollution and/or environmental issues with friends and family.

\subsection{CSR pillars' individual importance (related to brands recently purchased)}

Despite their high level of general knowledge of CSR and sustainability, the interview participants had quite a low level of knowledge or awareness regarding the CSR activities of any luxury brands. They seemed to "assume that brands do it" but did not exhibit any specific knowledge of particular examples. Their thinking about luxury brand-related CSR supported the previously mentioned findings where there was a lack of information leading to the assumption of brands' responsible behavior (Mohr \& Webb, 2005). The vast majority of respondents indicated high levels of general awareness and of all three pillars of CSR: economic, social and environmental, though the latter two were given more priority in terms of general importance. In terms of the pillar noted as most important to the respondents personally, most emphasized the environmental arena, followed by social and economic.

Examination of the initial results of scaling of the social, economic and environmental pillars related to the recently purchased brands, also indicates a low level of awareness regarding the CSR activities of brands. This is especially the case within the social and environmental pillars, where interview participants had little to no knowledge of organizations' CSR and sustainability activities. This was consistent across the recently purchased brands. There was noticeably more variance in the responses within the economic dimension of CSR.

None of the scaling results in any of the sustainable dimensions indicated a connection to brand purchase intent; in other words, there were no differences in this regard when it came to the brands that respondents claimed as the two most important luxury purchases made within the past year. Thus, it indicates that lack of knowledge of CSR activities within luxury is not specifically linked to particular brands, but is weak for the industry as a whole. This was confirmed by respondents' comments when discussing their knowledge of specific CSR activities of luxury brands: "No. I think they [luxury brands] do some activities, but they don't communicate [about them], so I don't know." The majority of the respondents also indicated that they feel better when purchasing from a socially responsible company. For example, they tend to agree with the statement: "Purchasing 
from a socially responsible company makes me feel like a better person, at the same time as fulfilling its principal functions."

The societal part of the sustainable dimension related to brands purchased tends to be very weak, with a mean of 2.7; most of the respondents did not know the answer for a brand they purchased. The most agreed upon statement was the following: "Brand $X$ is, regarding society, trying to sponsor cultural programs", followed by "trying to be highly committed to well-defined ethical principles" and "trying to sponsor cultural programes".

The environmental part of the sustainable dimension related to brand purchased tends to be similarily low in terms of agreement with given statements (2.8). For the most part, respondents stated they did not know the answer related the brand they purchased. Two statements were "rather agreed" in a majority of cases; these were "the brand is trying to protect the environment" and "trying to use only the necessary natural resources".

Respondents were rather positive regarding their purchased luxury brand in terms of the economic part of the sustainable dimension, where the mean was 2.1. Namely, the majority of them rather agreed with the following statements: "Brand $X$ is trying to build a solid relationship with its customers to assure its long-term economic success", and that brands try "to continuously improve the quality of the serices that they offer".

\subsection{Perception of individual luxury values}

Exploration of the functional, experiential, symbolic and social dimensions of the respondents' purchase intentions of luxury brands is summarized in Figure 2, which also illustrates the link to what has already been said above. In this context, the means aim to illustrate our theoretical input for development of a conceptual model, prior to validation during the quantitative research phase. The symbolic, experiential and functional values of the brands they bought recently are stronger purchase drivers compared to the CSR dimensions. In particular, the positive perception of the functional dimension of recently purchased luxury brands (mean 1.8) is driven by overall agreement that the brands are superior, sophisticated and of the best quality. The positive evaluation of the experiential value dimension of recently purchased luxury brands (mean 1.9) is driven by the perception of their uniqueness as well as the brand's attractiveness. Overall agreement with the symbolic value dimension (mean 1.7) is influenced by a high level of agreement with the statement that "the brand is striking, expensive and for the wealthy". The low level of agreement in the area of social influence (mean 3.4), meaning its influence on the purchase of luxury brands, is driven by disagreement with "I actively avoid using luxury branded products that are not in style." On the other hand, respondents tend to agree that "My friends and I tend to buy the same luxury brands." The social dimension, however, is very weak.

Despite respondents' positive general attitudes toward CSR and sustainability (mean 1.9), the sustainable dimensions are weaker in terms of possible impact on recent luxury 
purchases (mean 2.6) as respondents were not able to connect any socially responsible activities to the brand they recently purchased. However, the descriptive part showed that the questions asked made respondents consider the impact of companies' CSR seriously and they then wondered why they did not consider these dimensions more seriously during their shopping: "How come I don't know the approach of Rolex towards CSR?"; this phenomena is to be further explored in the quantitative stage.

Figure 2 | Indication of different dimensions' relations towards the purchase intention of luxury brands (1 - strongly agree, 5 - strongly disagree)

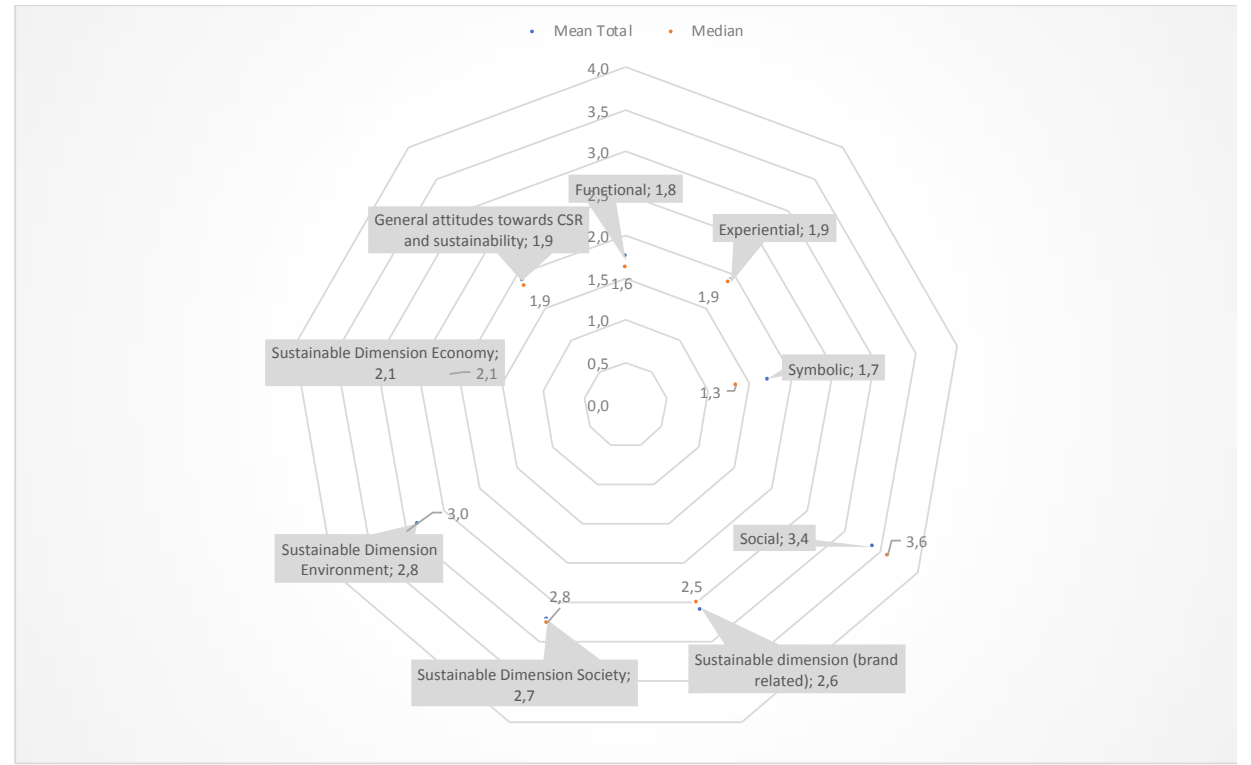

Source: Authors

\section{Discussion}

Three relationships emerged from the literature and the qualitative stage, as illustrated in Figure 3. The model suggests a relationship between purchase intention in the luxury segment (as the dependent variable) and luxury values (symbolic, experiential, functional and social as independent variables). The second suggested relationship presumes dependence between the purchase intention and the individual brand-related sustainable dimension, consisting of societal, environmental and economic (as independent variables), this being potentially moderated by certain conditions such as demographics and general attitudes towards CSR and sustainability. The third relationship emerged mainly from the qualitative pilot interviews, this being the dependence between brand-related CSR awareness and purchase intention, with the same moderating variables as in the previous two dependencies. Brand-related CSR awareness, originally part of the individual 
sustainable dimension, turned out to be a potentially significant influencer of purchase intention, and therefore is considered as a single independent variable in our model. A detailed view of the independent variables and measurement items may be found in Appendix A, at the end of this paper.

Figure 3 | Luxury purchase intention model assuming CSR impact

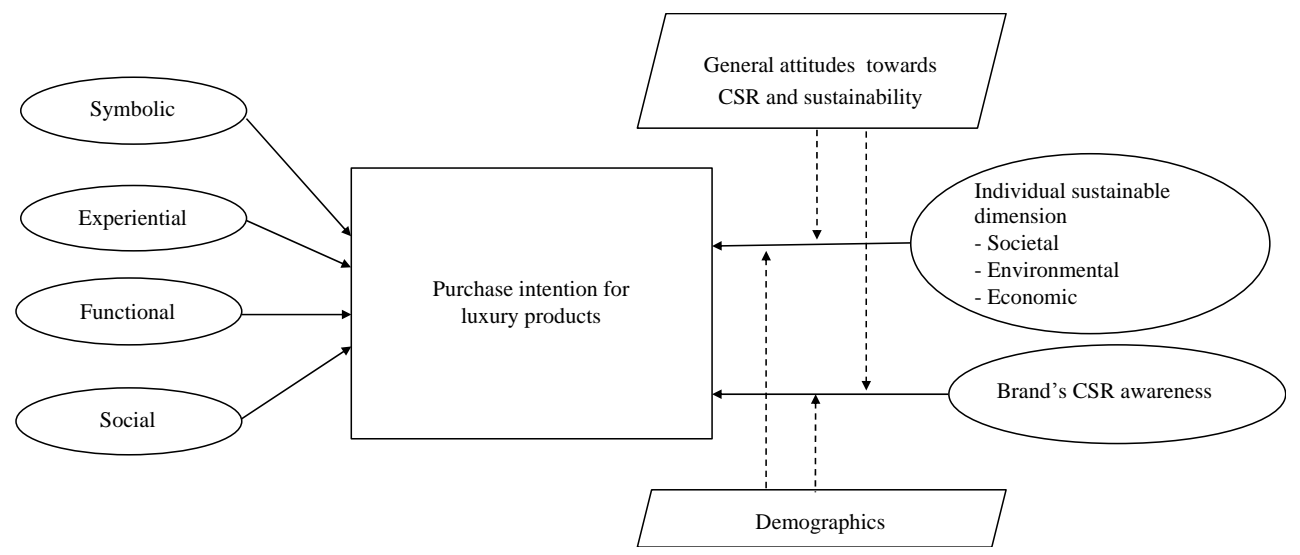

Source: Authors

To this end, as indicated in the descriptive part and the scaling of the dimensions as well as the literature review, we formulate the following propositions to be tested in a quantitative phase amongst luxury brand shoppers:

P1: The symbolic value dimension is positively related to luxury brand purchase intention.

P2: The experiential value dimension is positively related to luxury brand purchase intention.

P3: The functional value dimension is positively related to luxury brand purchase intention.

P4: The social value dimension is positively related to luxury brand purchase intention but is significantly weaker than the other dimensions in the model.

P5: The individual sustainable dimension has lower impact on luxury brand purchase intention compared to other dimensions in the model.

P6: The majority of luxury buyers have positive general attitudes toward CSR and sustainability issues but they are not actively influenced by them when buying 
luxury products due to a lack of knowledge about the CSR activities of the brands under study.

P7: General positive attitudes towards CSR and sustainability, together with certain demographics, positively influence the relationship between the individual sustainable dimension and purchase intention for luxury products.

P8: The age of respondents (i.e. young adults and parents of young adults) positively influences the relationship between the individual sustainable dimension and purchase intention for luxury products.

P9: The awareness of brand related CSR has a positive impact on purchase intention for luxury products and is positively influenced by demographics and general attitudes towards CSR and sustainability.

\section{Conclusion}

CSR marketing, defined as "campaigns that are not directly aimed at selling the products or services, but those that demonstrate the company's values, responsibility, sustainability and goodwill" (Haski-Leventhal, 2018, p. 311), means going beyond the conventional marketing mix to get a sustainable competitive advantage. Despite earlier findings that "luxury buyers' interest in sustainability when purchasing luxury goods is still relatively minimal“ (Kapferer \& Michaut-Denizeaut, 2014) and our characterization of the CSR activities of most luxury brands as being in the phase of "CSR Reluctance", slowly moving towards "CSR Cultural Grasp" (Maon et al., 2010), there are indicators that the position of luxury companies in their engagement towards CSR and their CSR marketing communication are going to change; CSR and its impact on customers is constantly evolving and will need to be linked to evolving customer values.

According to Bhattacharya and Sen (2004), consumers' lack of awareness about CSR initiatives is a major limiting factor in their ability to respond to these initiatives. They suggest that companies need to work on creating more CSR awareness while at the same time, they should avoid giving customers the impression that investment into CSR comes at the expense of the organization's core business (in which case, CSR might actually be perceived as negative rather than positive). The evolving consumer behavior is indicated in our research (“...but if I liked two similar products from different brands, I would buy the one which I knew followed CSR practices."). Nevertheless, the traditional values of the luxury brands (symbolic, experiential, functional, and social) still seem to have stronger resonance on purchase intent compared to the sustainable dimension. Therefore, the impact of luxury brand-related CSR awareness on purchase intention will be further explored in the next stage of our research, with the aim to provide the industry with evidence that this relationship is potentially one of the drivers for future growth. 
The shift towards greater emphasis may be supported by two key drivers on lux customers' side: (i) Millennial consumers who are reported to be twice as likely to support brands with strong management of environmental and social issues, and expect brands to not only manage their impact but communicate it (Positive Luxury, 2016); and (ii) Millennial investors who are twice as likely as the overall investor population to invest in companies targeting social or environmental goals (Morgan Stanley, 2017). Morgan Stanley reports that sustainable, responsible and impact investing rose 33\%, between 2014-2016 to USD 8.72 Trillion (Morgan Stanley, 2017). Our findings indicate that certain demographic factors (in terms of Millennial customers or customers with children Gen Z) are potentially moderating purchase intention, and should therefore be confirmed by further research in order to provide industry leaders with more rationale for their strategic CSR development. Regardless, sooner or later, companies will be forced by legislation to act and report about their sustainability efforts, and therefore integrating sustainability into business models is moving from a "good thing to do" to a legal obligation; there are also increased demands from stakeholders for transparency and action (Positive Luxury, 2016). As illustrated by other industries such as food, tobacco, or alcohol, it is wiser to act voluntarily and discuss potential ways with the authorities than to wait for strict regulations and controls.

While other researchers worked with artificial scenarios, i.e. where respondents imagined themselves in hypothetical product purchase situations, e.g. using shoes (Cheah et al., 2015; Mohr \& Webb, 2005) or handbags (Hung et al., 2011) as stimuli, our research has been conducted with real, active luxury customers and is based on their actual, recent purchases. The anonymity of respondents and artificial environment in which the other research was conducted may have contributed to the stronger perception of social values in their studies (Hung et al., 2011; Hennings et al., 2015) compared to ours, where the social aspect was the weakest. We intend to investigate this in more detail during the quantitative stage. Our efforts to use currently active luxury consumers placed a scale limit on our pilot study, due primarily to the extremely private nature of highly affluent luxury consumers, in what is also effectively an extremely niche market. However, the unique access we gained to this selective consumer group during the qualitative research phase is also what makes our findings so valuable. The authors are aware that the issue of access will be even more challenging when conducting quantitative research.

Nevertheless, based on current knowledge and recent trends, experience from other industries and both our literature review and the initial results from our pilot interviews, we expect the importance of CSR in the luxury industry to grow. While knowledge of particular CSR activities of specific brands was low, luxury buyers in our research had quite positive attitudes towards CSR in general, were rational, and very open to considering CSR as an added value to their shopping. There were indications that our sample would like to support organizations active within the spheres of CSR and sustainability. Thus, as a resulting output from our qualitative research study and the existing level of knowledge from the literature, we have developed a theoretical model and several propositions to test in an upcoming quantitative study, where we intend to explore 
the effects of CSR and sustainability issues on luxury brand purchase intention in depth. The need for a deep understanding of how CSR activities influence consumer responses was suggested by Fatma and Rahman (2015), who conducted classification of literature on consumer perspectives toward CSR. The same source concludes that most of the studies have been done in countries like the USA, the UK and Spain - China was an exception in the published studies - and the Central European perspective is not yet included in current literature.

In terms of future research, the authors are considering the potential of studying the impact of corporate social responsibility on consumers' purchase intention at several different points in time, to see if, how and to what extent, there is any evolution among responses. In conclusion, when CSR becomes an essential part of a company's culture, organization and processes, it will integrate and respect three critical components: the organization's self-interests, its rights and also its responsibilities. To the extent that the responsibilities expected of it do not infringe upon its rights and align with its self-interest, the chance of introducing meaningful change and building a more sustainable economic model increases (Chandler, 2017).

\section{References}

Alvarado-Herrera, A., Bigne, E., \& Aldas-Manzano, J. (2017). A Scale for Measuring Consumer Perceptions of Corporate Social Responsibility Following the Sustainable Development Paradigm. Journal of Business Ethics, 140(2), 243-262.

Bendell, J., \& Kleanthous, A. (2007). Deeper luxury: quality and style when the world matters. Retrieved November 9, 2017, from http://aidagency.typepad.com/good_stuff/files/DeeperluxuryReport.pdf.

Bhattacharya, C. B., \& Sen, S. (2004). Doing beter at doing good: When, why and how consumers respond to corporate social initiatives. California Management Review, 47(1), 9-22.

Bryman, A. (2006). Integrating quantitative and qualitative research: how is it done? Qualitative Research, 6(1), 97-113.

Carroll, A. B. (1991). The pyramid of corporate social responsibility: Toward the moral management of organizational stakeholders. Business Horizons, 34, 39-48.

Carroll, A. B. (1999). Corporate social responsibility. Evolution of a definitional construct. Business and Society, 38(3), 268-295.

Chandler, D. (2017). Strategic Corporate Social Responsibility: Sustainable Value Creation. Thousand Oaks, CA: SAGE Publications.

Cheah, I., Phau, I., Chong, C., \& Shimul, A. S. (2015). Antecedents and outcomes of brand prominence on willingness to buy luxury brands. Journal of Fashion Marketing and Management, 19(4), 402-415.

CSR Europe (2017). Goals (SDGs): The Value for Europe (A Whitepaper by Frost \& Sullivan and GlobeScan on behalf of CSR Europe). Retrieved August 2018, from CSR Europe:

https://www.csreurope.org/sites/default/files/FS_WP_Sustainable\%20Developme nt\%20Goals_05112017_RD_0.pdf.

Davies, I. A., Lee, Z., \& Ahonkhai, I. (2012). Do Consumers Care About Ethical-Luxury? Journal of Business Ethics, 106(1), 37-51. 
Deloitte (2017). Global Powers of Luxury Goods 2017. Retrieved November 4, 2017, from https://www2.deloitte.com/content/dam/Deloitte/global/Documents/consumerindustrial-products/gx-cip-global-powers-luxury-2017.pdf.

Du, S., Bhattacharya, C. B., \& Sen, S. (2011). Corporate Social Responsibility and Competitive Advantage: Overcoming the Trust Barrier. Management Science, 57(9), 1528-1545.

Dubois, B., \& Laurent, G. (1993). Is There a Euro Consumer For Luxury Goods? European Advances in Consumer Research, 1, 58-69.

Dubois, B., \& Paternault, C. (1995). Observations: understanding the world of international luxury brands. Journal of Advertising Research, 35(4), 69-76.

Fatma, M., \& Rahman, Z. (2015). Consumer perspective on CSR literature review and future research agenda. Management Research Review, 38(2), 195-216.

Han, Y. J., Nunes, J. C., \& Dreze, X. (2010). Signaling Status with Luxury Goods: The Role of Brand Prominence. Journal of Marketing, 74(4), 15-30.

Haski-Leventhal, D. (2018). Strategic Corporate Social Responsibility. Los Angeles: SAGE Publications.

Heine, K. (2012). The concept of luxury brands. Retrieved November 14, 2017, from http://www.conceptofluxurybrands.com/content/20121107_Heine_The-Conceptof-Luxury-Brands.pdf.

Hennings, N., Wiedmann, K.-P., Klarmann, C., \& Behrens, S. (2015). The complexity of value in the luxury industry. International Journal of Retail \& Distribution Management, 40(10/11), 922-939.

Ho, H. C., Awan, M. A., \& Khan, H. U. (2016). Luxury brands and corporate social responsibility: A perspective on consumers' preferences. Journnal of International Management Studies, 16(1), 77-81.

Hung, K.-p., Chen, A. H., Peng, N., Tiwsakul, R. A., \& Chou, C.-1. (2011). Antecedents of Luxury Brand Purchase Intention. Journal of Product \& Brand Management, 20(6), 457-468.

Interbrands (2017). Best Global Brands. Retrieved December 18, 2017, from www.interbrands.com: http://interbrand.com/best-brands/best-globalbrands/2016/ranking/\#?listFormat=sq\&filter=Europe $\% 20 \% 26 \% 20$ Africa $\% 2$ CLux ury.

Kale, G. Ö., \& Öztürk, G. (2016). The importance of sustainability in luxury brand management. Intermedia International e-Journal, 3(4), 106-126.

Kapferer, J. N., \& Bastien, V. (2012). The Luxury Strategy: Break the Rules of Marketing to Build Luxury Brands. London: Kogan Page.

Kapferer, J., \& Michaut-Denizeaut, A. (2014). Is Luxury Compatible with Sustainability? Luxury Consumers' Viewpoint. Journal of Brand Management, 21(1), 1-22.

Lin, C. P., Chen, S. C., Chiu, C. K., \& Lee, W. Y. (2011). Understanding purchase intention during product-harm crises: moderating effects of perceived corporate ability and corporate social responsibility. Journal of Business Ethics, 102(3), 455-471.

Maon, F., Lindgreen, A., \& Swaen, V. (2010). Organizational stages and cultural phases: A critical review and a consolidative model of corporate social responsibility development. International Journal of Management Reviews, 12(3), 20-38.

Mohr, L. A., \& Webb, J. D. (2005). The effects of corporate social responsibility and price on consumer responses. The Journal of Connsumer Affairs, 39(1), 121-147. 
Moon, H.-C., Parc, J., Yim, S. H., \& Park, N. (2011). An Extension of Porter and Kramer's Creating Shred Value (CSV): Reorienting Strstegies and Seeking International Cooperation. Journal of International and Area Studies, 18(2), 49-64.

Morgan Stanley (2017). Millennials Drive Growth in Sustainable Investing. Morgan Stanley. Retrieved November 18, 2017, from:

https://www.morganstanley.com/ideas/sustainable-socially-responsible-investingmillennials-drive-growth.

Positive Luxury (2016). Positive Luxury's 2016 Predictions for the Luxury Industry: Sustainability \& Innovation. Retrieved November 18, 2017, from Positive Luxury: http://positiveluxury.msgfocus.com/files/amf_pets_pyjamas/project_173/2016_Pr edictions_for_the_Luxury_Industry_in_Sustainability_and_Innovation__The_Executive_Summary.pdf.

Positive Luxury (2017). The Hong Kong fur trade, and how Gucci's ban could affect it. Retrieved November 15, 2017, from https://blog.positiveluxury.com/2017/11/14/news-supply-chain-becoming-partluxury-designers-branding-strategies/\#newssection2.

Robertson, J. (2018). Can luxury be socially responsible? How luxury brands frame their corporate social responsibility online. Annals in Social Responsibility, 4(1), 1012.

Schutt, K. R. (2015). Qualitative Data Analyses. In K. R. Schutt (Ed.), Investigating the Social World. The Process and Practice of Research. Los Angeles: SAGE Publications.

Sharma, V., Jeannne, P., Mohanta, S., \& Liza, E. A. (2018). Influence of the dimensions of CSR activities on consumer purchase intention. Innovative Marketing, 14(1), 2332.

Sreejesh, S., \& Mohapatra, S. (2014). Mixed Method Research Design. New York: Springer.

Sustainable Brands (2017). Kering to Transform Luxury Industry with Next-Gen Sustainability Strategy. Retrieved August 2018, from https://www.sustainablebrands.com/news_and_views/business_models/libby_mac carthy/kering_transform_luxury_industry_next_gen_sustainable.

Trendwatching (2018). Annual Trend Report. Retrieved November 9, 2017, from www.trendwatching.com.

United Nations (1987). Our Common Future, Chapter 2: Towards Sustainable Development. Retrieved November 2, 2017, from Our: http://www.undocuments.net/our-common-future.pdf.

United Nations (2015). Sustainable Development Knowledge Platform. Retrieved August 2018, from https://sustainabledevelopment.un.org/post2015/transformingourworld.

Wong, J., \& Dhanesh, G. (2017). Corporate social responsibility (CSR) for ethical corporate identity management. Framing CSR as a tool for managing the CSRluxury pradox online. Corporate Communications: An International Journal, 22(4), 420-439. 


\section{Authors}

\section{Květa Olšanová, Ph.D.}

Assistant Professor

Department of International Business

Faculty of International Relations

University of Economics, Prague

Nám. W. Churchilla 4, 13067 Prague 3, Czech Republic

kveta.olsanova@vse.cz

\section{Gina Cook, Ph.D.}

Assistant Professor

Department of Management

Director, International Business Programs

Metropolitan State University of Denver

PO Box 173362, Denver, CO 80217 USA

gcook13@msudenver.edu

\section{Marija Zlatić, Ph.D.}

Assistant Professor

Department of International Business

University of Economics, Prague

Nám. W. Churchilla 4, 13067 Prague 3, Czech Republic

marija.zlatic@vse.cz 


\section{Appendix A: Independent variables and measurement items}

\begin{tabular}{|c|c|c|}
\hline \multirow{2}{*}{$\begin{array}{l}\text { Independent } \\
\text { Variables }\end{array}$} & \multicolumn{2}{|r|}{ Measurement Items } \\
\hline & \multicolumn{2}{|c|}{ I strongly disagree (1) / strongly agree (5) } \\
\hline $\begin{array}{l}\text { Functional value } \\
\text { dimension }\end{array}$ & Luxury brand X's & $\begin{array}{ll}- & \text { product is handmade (crafted) } \\
- & \text { has the best quality } \\
- & \text { is sophisticated } \\
- & \text { is superior }\end{array}$ \\
\hline $\begin{array}{l}\text { Experiential } \\
\text { value dimension }\end{array}$ & \multicolumn{2}{|l|}{ Luxury brand X's } \\
\hline $\begin{array}{l}\text { Symbolic value } \\
\text { dimension }\end{array}$ & \multicolumn{2}{|l|}{ Luxury brand X's } \\
\hline Social influence & \multicolumn{2}{|c|}{$\begin{array}{l}\text { - } \quad \text { Before purchasing a luxury branded product, it is important to know } \\
\text { what brands will make good impression on others. } \\
\text { - } \quad \text { My friends and I tend to buy the same luxury brands. } \\
\text { - } \quad \text { Before purchasing a luxury branded product, it is important to know } \\
\text { what kinds of people buy certain brands. } \\
\text { - I tend to pay attention to what other luxury brands others are } \\
\text { buying. } \\
\text { I like to know what luxury branded products make good } \\
\text { impressions on others. } \\
\text { - I actively avoid using luxury branded products that are not in style. }\end{array}$} \\
\hline \multirow{4}{*}{$\begin{array}{l}\text { Individual } \\
\text { sustainable } \\
\text { dimension }\end{array}$} & $\begin{array}{l}\text { When I buy luxury } \\
\text { brand X: }\end{array}$ & I am aware of its social responsible activities. \\
\hline & $\begin{array}{l}\text { In my opinion } \\
\text { regarding society, } \\
\text { brand } X \text { is really: }\end{array}$ & $\begin{array}{l}\text { Trying to sponsor educational programs } \\
\text { Trying to be highly committed to well-defined } \\
\text { ethical principles } \\
\text { Trying to sponsor cultural programs } \\
\text { Trying to make financial donations to social causes } \\
\text { Trying to help to improve quality of life in the hotel } \\
\text { community }\end{array}$ \\
\hline & $\begin{array}{l}\text { In my opinion } \\
\text { regarding the } \\
\text { environment, } \\
\text { brand } X \text { is really }\end{array}$ & $\begin{array}{l}\text { Trying to sponsor pro-environmental programs } \\
\text { Trying to allocate resources to offer services } \\
\text { compatible with the environment } \\
\text { Trying to carry out programs to reduce pollution } \\
\text { Trying to protect the environment } \\
\text { Trying to recycle its waste materials properly } \\
\text { Trying to use only the necessary natural resources }\end{array}$ \\
\hline & $\begin{array}{l}\text { In my opinion } \\
\text { regarding the }\end{array}$ & $\begin{array}{l}\text { Trying to maximize profits in order to guarantee its } \\
\text { continuity }\end{array}$ \\
\hline
\end{tabular}




\begin{tabular}{|c|c|c|}
\hline \multirow{2}{*}{$\begin{array}{l}\text { Independent } \\
\text { Variables }\end{array}$} & \multicolumn{2}{|r|}{ Measurement Items } \\
\hline & $\begin{array}{l}\text { economy, brand } \\
\mathrm{X} \text { is really }\end{array}$ & $\begin{array}{l}\text { Trying to build solid relations with its customers to } \\
\text { assure its long-term economic success } \\
\text { Trying to continuously improve the quality of the } \\
\text { services that they offer } \\
\text { Trying to have a competitive pricing policy } \\
\text { Trying to always improve its financial performance } \\
\text { Trying to do its best to be more productive }\end{array}$ \\
\hline $\begin{array}{l}\text { Brand's CSR } \\
\text { awareness }\end{array}$ & \multicolumn{2}{|c|}{$\begin{array}{l}\text { Purchasing from a socially responsible company makes me feel } \\
\text { like a better person at the same time as fulfilling its principal } \\
\text { function. } \\
\text { When I buy luxury brand X, I am aware of its socially responsible } \\
\text { activities. }\end{array}$} \\
\hline $\begin{array}{l}\text { General } \\
\text { attitudes } \\
\text { towards CSR } \\
\text { and } \\
\text { sustainability } \\
\text { issues }\end{array}$ & \multicolumn{2}{|c|}{$\begin{array}{l}\text { - One should limit car usage in city centers. } \\
\text { - } \quad \text { I am concerned about environment degradation. } \\
\text { - I am ready to boycott a company that does not comply with social } \\
\text { and environmental regulations. } \\
\text { - It is through technical progress that we will find solutions to prevent } \\
\text { environmental degradation. } \\
\text { - } \quad \text { It is by significantly modifying our lifestyles that can prevent the } \\
\text { degradation of the environment. } \\
\text { - } \quad \text { I prefer healthy products, without risk to my health. } \\
\text { - I often talk about pollution and the environment with my family, } \\
\text { children, and friends. } \\
\text { During elections, issues regarding the environment are } \\
\text { instrumental in my choice of candidate/parties. } \\
\text { - I am in favor of awarding a penalty for products negatively } \\
\text { impacting the environment. } \\
\text { I am interested in sustainable development. }\end{array}$} \\
\hline
\end{tabular}

